ISSN: 2614-1280, http://www.jurnal.stie-aas/ijebar

\title{
IMPROVING REGIONAL ORIGINAL INCOME WITH TAX RECEIPT, REGIONAL RETRIBUTION AND REGIONAL WEALTH MANAGEMENT RESULTS IN SOLO RAYA
}

\author{
Suprihati, LMS ${ }^{1}$ Kristiyanti ${ }^{2}$ Hajir $^{3}$ \\ The College of Economics AAS Surakarta \\ Email:suprihati4566@gmail.com
}

\begin{abstract}
Abstarct
: This study uses secondary data, which comes from the realization of District / City Regional Revenues in the Surakarta Residency 2012-2016 Fiscal Year. The data analysis using multiple linear regression analysis with the help of SPSS 20. The results of the study indicate that tax revenue has a significant effect on the Original Revenue of District / City Regions in the Surakarta Residency. Whereas the regional retribution does not have a significant effect on the Original Revenue of District / City Regions in the Surakarta Residency. Regional wealth management has a significant effect on the District / City Regional Original Revenue in the Residency. Tax revenues, regional retributions and management of regional wealth together influence the Original Revenue of District / City Regions in the Surakarta Residency. The calculation results show that tax revenue has a value of beta coefficient of 0.442 which is greater than the variable regional levies and regional wealth management. This shows that tax revenue is more dominant in influencing the Original District / City Revenue in the Surakarta Residency.
\end{abstract}

Keywords $\quad:$ tax revenue, regional retribution, management of regional wealth, local revenue.

\section{Background}

National development begins with the construction of a strong economic foundation so as to create economic growth and aims to improve the welfare of the community. For this reason, the government must try to increase revenue to support development success. The success of development can be achieved by the existence of strong acceptance, where financing sources are endeavored to continue to rely on domestic revenues, both oil and gas and non-oil and gas.

The most central government revenue is tax, the tax contribution to the government budget is very large, so the role of tax is so central. For this reason, the government always strives to increase income from the tax sector, through efforts to eradicate the tax mafia. The government is currently improving its tax system because the old system is considered to have many weaknesses, this is done to 
secure state income from the tax sector so as not to leak, and this effort is carried out so that state revenues from taxes from years continue to increase.

Development independence is needed both at the central level and at the regional level. This is inseparable from the success of the implementation of provincial and city or city government which is an integral part of the central government with its policies. The policy on regional finance is taken by the central government so that the regional government has the ability to finance regional development in accordance with the principles of the autonomous region. Regional financing first comes from the central government only. With the existence of autonomy, financing not only comes from the center but also comes from its own region, so that the local government tries to increase the Regional Original Revenue itself. To increase Regional Original Revenue, the government tries to improve its regional tax system. Local tax is the largest income obtained by the region.

Surakarta Residency is a Regency / City that has a good economy in Central Java Province. In order to improve the welfare of the community, the Regency / City Government in the Surakarta Residency is trying to increase the Regional Original Revenue, one of which is through regional taxes and levies, as well as the results of separated regional wealth management. In the Surakarta Regency / City the local tax collection system is different from the central government tax. The difference lies in the withdrawal system, local taxes in the ExResidency Regency / City of Surakarta are drawn directly by government employees and there are certain taxes, where taxpayers can pay directly at the office that directly handles regional income, in this case the Regency / City in Ex Residency. Surakarta is charged to the DPPKA. Local retribution collection system uses tickets.

Tickets are proof of payment from providing services to the public. This difference minimizes the existence of leaks from the Regional Original Income from the regional tax and regional retribution sectors. And no less important is the existence of a share of profits on equity participation in regional-owned companies (BUMD). With this, it is expected that it will increase Regional Original Revenue from local taxes, regional retribution and the results of regional wealth management. There is a close link between regional revenues, economic development and community welfare. Where the higher the revenue received by the region, the higher the opportunity to develop regional economy and the welfare of the community. Potentials in the Ex-Regency / City of Surakarta Residency should be maximized again to increase the source of revenue received by the region.

\section{Underlying Theory}

\subsection{Tax}

Tax is the contribution of the people to the state treasury based on the law (which can be imposed) by not getting a counter-payment service which can be directly shown and used to pay general expenditure (Mardiasmo, 2012). In general terms, tax is a mandatory contribution to the state. He defended this definition (as a correction from the first part of its original 
definition), so that the tax is the transfer of wealth from the people to the state treasury to finance routine expenditure and the 'surplus' is used for public savings which is the main source for financing investment public (public investment) (Suandy, 2013).

According to Erly Suandy (2013), tax sharing can be carried out based on class, nature, and authority (the collecting agency). According to the class, taxes are grouped into two, namely Direct Tax and Indirect Tax. Direct tax is a tax that must be borne or borne by the taxpayer alone and cannot be delegated or charged to other people or other parties. Taxes must be borne by the taxpayers themselves. Example: Income Tax, Income Tax is paid or borne by certain parties who earn the income. Indirect Tax is a tax that can eventually be charged or delegated to another person or third party. Taxes do not directly occur if there is an activity, event, and an act that causes tax payable, for example the delivery of goods or services. Example: Value Added Tax and Sales Tax on Luxury Goods. By their nature, taxes can be grouped into two, Subjective Taxes and Objective Taxes.

Subjective tax is a tax that imposes attention to the personal conditions / conditions of taxpayers or taxation that pay attention to the state of the subject. Example: Income Tax. Taxes that impose attention to the object either in the form, objects, circumstances, actions, or events that result in the emergence of the obligation to pay taxes, without regard to the personal condition of the tax subject (taxpayer) or residence. Example: Value Added Tax and Sales Tax on Luxury Goods. Central Tax or State Tax is a tax whose collection authority rests with the central government whose implementation is carried out by the Ministry of Finance through the Directorate General of Taxes and is used to finance the country's household.

Law Number 18 of 1997 and Law Number 34 of 2000 do not explicitly and clearly determine what constitutes a tax object for each type of local tax, but submit it to government regulations. Determination of what is the object of regional tax at this time can be seen in Government Regulation Number 65 of 2001 concerning Regional Taxes, which are substitutes of Government Regulation Number 19 of 1997 concerning Regional Taxes. This is the determination of tax objects in general, given the application of a type of local tax in a province or city / city stipulated by local regulations to find out what constitutes a tax object must be seen what the regional regulation stipulates as a tax object (Kurniawan, 2010).

In collecting local taxes, there are terms that are sometimes equated even though they actually have different meanings, namely the tax subject and the taxpayer. Tax subjects are individuals or entities that can be subject to local taxes. Thus, anyone who is either an individual or an entity, who meets the objective requirements specified in a regional regulation concerning regional tax, will be the subject. Meanwhile, taxpayers are individuals or entities who, according to regional taxation laws, are required to pay tax payable, including certain tax collectors or cutters. Therefore, a person or an entity becomes a taxpayer if it has been determined by regional regulations to 
make tax payments, as well as the person or body authorized to collect taxes from the tax subject. This shows that the taxpayer can be a tax subject to the obligation to pay taxes or other parties who are not tax subjects, who are authorized to collect taxes from the subject of the taxpayer (Kurniawan, 2010).

According to the Law Number 34 of 2000, Regional Retribution is a regional levy as payment for certain special services or grants provided and or provided by the local government for the benefit of individuals or entities (Suandy, 2013). Objects of Regional Retribution according to Mardiasmo (2012) consist of: (1) Public Services in the form of services provided or provided by local governments for the purpose of public interest and benefit and can be enjoyed by individuals or entities. (2) Business Services in the form of services provided by the local government by adhering to the commercial principle. (3) Specific Licensing, namely certain activities of regional government in the framework of granting licenses to individuals or entities intended to guide, regulate, control, and supervise activities in space utilization, use of natural resources, goods, infrastructure, facilities or certain facilities for protect public interests and preserve the environment.

According to Mardiasmo (2012) the subject of Regional Retribution is: (1) Subjects of Public Service Levy are individuals or bodies that use / enjoy the relevant public services. (2) The subject of business service levies is an individual or entity that uses / enjoys the business services concerned. (3) Subjects of Certain Licensing Levies are individuals or bodies that obtain certain permits from the regional government. According to Mardiasmo (2012) the principles and objectives of tariff setting for each type of Regional Retribution are as follows: (1) Public Service levies based on regional policies taking into account the costs of providing related services, community capabilities, and aspects of justice. (2) Business Services levies are based on the aim of obtaining a reasonable profit as the benefits deserved by similar private entrepreneurs operating efficiently and oriented to market prices. (3) Certain Licensing Levies, based on the objective to cover part or all of the costs of administering the relevant permit.

\subsection{Results of Regional Wealth Management}

The results of the management of the separated regions are regional revenues derived from the management of regional assets which are separated, broken down according to the objects of income which include the share of profits on capital participation in regional-owned enterprises (BUMD), the share of profits on capital participation in state-owned enterprises (BUMN) and the share of profit on equity participation in private-owned companies and community groups (Mardiasmo, 2012). Regional Original Revenue is categorized in the routine Regional Income and Expenditure Budget (APBD). Regional Original Income is an income that shows an area's ability to collect sources of funds to finance routine and development activities. So the understanding of Regional Original Revenue can be said to be routine income 
ISSN: 2614-1280, http://www.jurnal.stie-aas/ijebar

from the efforts of local governments in utilizing the potential of their regional financial resources to finance their duties and responsibilities (Kurniawan, 2010).

Regional Original Income (PAD) according to Law Number 33 of 2004 by Septian Dwi Kurniawan consists of regional revenues from the regional tax sector, regional retribution, the results of regionally owned companies, the results of the processing of separated regional assets, and other legitimate income. The Act also states that the purpose of Regional Original Revenue is to give the regions freedom to explore funding for the implementation of regional autonomy as a manifestation of decentralization. One effort to see the ability of the region in the context of self-support in terms of regional finance in order to reduce dependence on the central government, is to look at the composition of the existing regional revenues. The greater the composition of Regional Original Revenue, the greater the ability of local governments to assume greater responsibility. But the smaller the composition of Regional Original Revenue towards regional revenues, the greater dependence on the center. While the impact felt by the community with an increase in revenue from the region's original revenue is the smooth development. Development includes various sectors including road construction, construction of public facilities and other facilities (Kurniawan, 2010).

Sources of financing for the implementation of decentralization consist of Regional Original Revenues (PAD), Balancing Funds, Regional Loans and others Legal receipts. Sources of Regional Original Revenue are regional financial resources that are excavated within the relevant region, which consists of: (1) Regional Taxes are regional levies according to regional regulations that are used to finance regional household affairs as public legal entities. (2) Regional levies constitute regional levies as payment of usage or because of obtaining services or jobs or services of local government and regional-owned business services for those who are interested in the services provided by the region, either directly or indirectly. (3) The portion of a Regionally-Owned Enterprise is the share of profits or net profit from a regional company on another entity which is a regionally-owned enterprise. Whereas regional companies are companies whose capital is partially or completely constitutes separated regional assets. (4) This acceptance includes the rent of the regional official house, the rent of the building and the land owned by the region, the demand deposit service, the proceeds from the sale of used goods belonging to the region and other legitimate receipts according to the Law (Kurniawan, 2010).

\subsection{Framework}

There needs to be a framework of thought which is the basis for researching problems that aim to find, develop and test the truth of a research can be described as follows: 
ISSN: 2614-1280, http://www.jurnal.stie-aas/ijebar

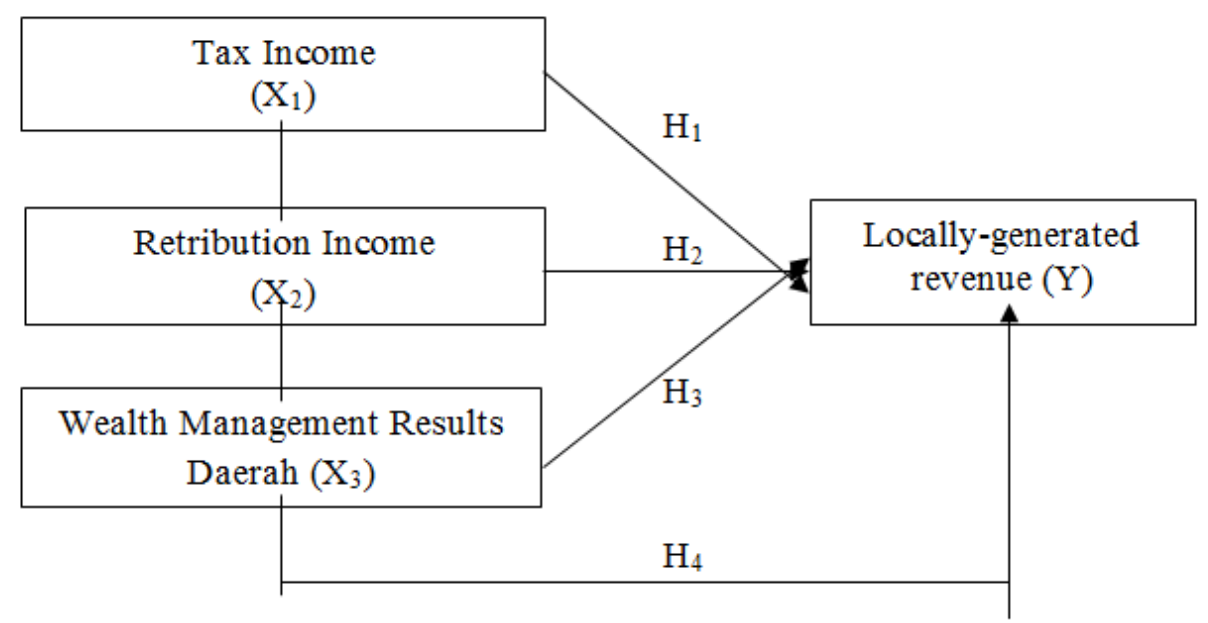

Figure.Framework

\section{Research Method}

\subsection{Data Analysis Method}

Data analysis is done after data is collected. The process of data analysis is an attempt to obtain answers to research problems. Data analysis that can be used in the study is the Multiple Linear Regression Model. Regression is the main estimation method in econometrics. Regression analysis is used to find out how the dependent variable can be predicted through independent variables, individually. Thus, regression analysis can be used to decide whether the increase and decrease of independent variables can be done by increasing and decreasing the state of the independent variables, or to improve the state of the dependent variable can be done by increasing the independent variables and vice versa (Sugiyono, 2012).

Whereas a multiple linear regression model is used to predict or predict how the state (ups and downs) of the dependent variable, if two or more independent variables as predictor factors are manipulated (raised by value). So multiple linear regression analysis will be done if there are at least 2 independent variables (Sugiyono, 2012). Multiple linear regression equations for two independent variables (predictors) are stated as follows: $\mathbf{Y}=\boldsymbol{B}_{0}+\boldsymbol{B}_{1} \mathbf{X}_{1}+\boldsymbol{B}_{2} \mathbf{X}_{2}+\boldsymbol{B}_{3} \mathbf{X}_{\mathbf{3}}+\mathbf{e}$

Testing the hypothesis in this study was carried out using multiple linear regression. Multiple regression analysis aims to find out the influence of paja revenue, regional retribution and management of regional wealth on the District / City Original Revenue in the Surakarta Residency in 2012-2016. As for the calculation, the following results are obtained:

\section{Table 1 Hypothesis Testing Results}

\begin{tabular}{|l|c|c|c|c|}
\hline \multicolumn{1}{|c|}{ Variabel } & Coefficient & Beta & T $_{\text {count }}$ & Sig \\
\hline (Constant) & 59416200506,428 & & 2,166 & 0,038 \\
Tax Income & 0,479 & 0,442 & 2,936 & 0,006
\end{tabular}


ISSN: 2614-1280, http://www.jurnal.stie-aas/ijebar

\begin{tabular}{|l|c|c|c|c|} 
Regional Retribution & 0,788 & 0,135 & 1,015 & 0,318 \\
Wealth Management & 11,282 & 0,433 & 3,811 & 0,000 \\
\hline Adj. $\mathrm{R}^{2} \quad=0,688$ & & & \\
$\mathrm{~F}_{\text {count }}=25,974$ & & & \\
$\mathrm{~F}_{\text {table }} \quad=2,91$ & & & \\
$\mathrm{t}_{\text {table }} \quad=2,042$ & & & \\
\hline
\end{tabular}

Source: Indonesia Stock Exchange, 2018 processed

From Table 4.6 which is the result of multiple linear regression testing, the regression equation can be made as follows:

\section{$Y=59416200506,428+0,479 X_{1}+0,788$ $\mathrm{X}_{2}+11,282 \mathrm{X}_{2}$}

The results of calculations for the effect of tax revenue on the District / City Original Revenue in Surakarta Residency in 2012-2016 obtained the value of $t_{\text {count }}$ of 2.936 and $\mathrm{p}=0.006$ with the regression coefficient value (b1) of 0.479 with positive parameters. This shows that every time there is an increase in tax revenue of Rp. 1, it will increase the Regional Original Income by Rp. 0.479 with the assumption that the other variables are constant.

The effect of blood retribution on District / City Original Revenue in Surakarta Residency in 2012-2016 obtained $t_{\text {count }}$ of 1.015 and $p=0.318$ with regression coefficient value (b2) of 0.788 with positive parameters. This shows that every time there is an increase in regional retribution of $\mathrm{Rp}$. 1, it will increase the Regional Original Revenue of Rp. 0.788 assuming other variables are constant.
The influence of the management of regional wealth on the District / City Original Revenue in the Surakarta Residency in 2012-2016 was obtained $t_{\text {count }}$ of 3.811 and $p=0.001$ with the regression coefficient value (b3) of 11.228 with positive parameters. This shows that every time there is an increase in the management of regional wealth of Rp. 1, it will increase the Regional Original Revenue of Rp. 11,282 assuming other variables are constant.

The calculation results show that tax revenue has a value of beta coefficient of 0.442 which is greater than the variable regional levies and regional wealth management. This shows that tax revenue is more dominant in influencing the Original District / City Revenue in the Surakarta Residency, then the testing will be carried out with the coefficient of determination ( $\mathrm{R} 2), \mathrm{F}$ test and $\mathrm{t}$ test to ensure the relationship in the hypothesis.

\subsubsection{Coefficient of Determination (Adj. $\mathbf{R}^{2}$ )}

The coefficient of determination is to measure the proportion or percentage of contributions from all the independent variables $(\mathrm{X})$ contained in the regression model of the dependent variable (Y).

Table 4.7.

Determination Coefficient Test (Adj. $\mathbf{R}^{\mathbf{2}}$ )

\begin{tabular}{|l|l|l|l|c|}
\hline Model & $\mathrm{R}$ & R Square & $\begin{array}{c}\text { Adjusted } \\
\text { R Square }\end{array}$ & $\begin{array}{c}\text { Std. Error of the } \\
\text { Estimate }\end{array}$ \\
\hline
\end{tabular}


International Journal of Economics, Business and Accounting Research (IJEBAR)

Peer Reviewed - International Journal

Vol-2, Issue-3, 2018 (IJEBAR)

ISSN: 2614-1280, http://www.jurnal.stie-aas/ijebar

\begin{tabular}{|l|l|l|l|l|}
\hline 1 & 0.846 & 0.715 & 0.688 & 45688247376.946 \\
\hline
\end{tabular}

Source: Statistics Indonesia, 2018 processed

Calculation results for Adj value. $\mathrm{R}^{2}$ with the help of SPSS 20.0 for Windows program, in multiple regression analysis obtained the coefficient of determination or Adj. $\mathrm{R}^{2}$ is 0.688 . This means that variations in changes in Blood Original Revenue in Districts / Cities in Surakarta Residency $68.8 \%$ can be explained by changes in tax revenue, regional retribution and management of regional wealth, while the remaining $37.8 \%$ is explained by other factors that are not observed.

\subsubsection{F Test}

This test is used to test the significance of regression coefficients together whether there is an influence between tax revenue, regional retribution and management of regional wealth (independent variables) with Regional Original Income (dependent variable), using a $5 \%$ confidence level obtained $\mathrm{F}_{\text {table }}$ values on df: $3 ; 31$ of 2.91 .

Table 4.8. Goodness of Fit Test Results (Test F)

\begin{tabular}{|c|c|c|c|c|}
\hline Model & $\mathrm{F}_{\text {hitung }}$ & $\mathrm{F}_{\text {tabel }}$ & $p$ & Keterangan \\
\hline Regression & 25,974 & 2,91 & 0,000 & $\mathrm{H}_{0}$ ditolak \\
\hline
\end{tabular}

Source: Statistics Indonesia, 2018 processed

The steps to test the null model and the alternative hypothesis are as follows: $b$

\subsubsection{Hypothesis Determination}

$\mathrm{H}_{0}: \mathrm{b} 1=\mathrm{b} 2=\mathrm{b} 3=0$, it means that tax revenue, regional retribution and management of regional assets together do not have a significant effect on Regional Original Revenue.

$\mathrm{H}_{\mathrm{a}}: \mathrm{b} 1 \neq \mathrm{b} 2 \neq \mathrm{b} 3 \neq 0$, it means that tax revenue, regional retribution and management of regional assets together have a significant effect on Regional Original Income.

\subsubsection{Level of Significant Determination}

The significant level used in this study is $\alpha=0.05$.

$$
\begin{aligned}
\mathrm{F}_{\text {table }} & =0,05(\mathrm{k}-1 ; \mathrm{n}-\mathrm{k}) \\
& =0,05(4-1 ; 35-4) \\
& =0,05(3 ; 31) \\
& =2,91
\end{aligned}
$$

\subsubsection{Testing Criteria}

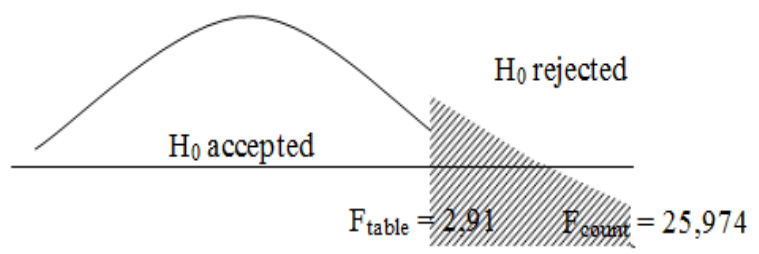

Apabila $\mathrm{F}_{\text {count }} \leq 2,91$, then $\mathrm{H}_{0}$ accepted.

Apabila $\mathrm{F}_{\text {count }}>2,91$, then $\mathrm{H}_{0}$ rejected 
International Journal of Economics, Business and Accounting Research (IJEBAR)

Peer Reviewed - International Journal

Vol-2, Issue-3, 2018 (IJEBAR)

ISSN: 2614-1280, http://www.jurnal.stie-aas/ijebar

\subsubsection{The calculation results}

The calculation results obtained through SPSS.20 for windows are 25,974.

\subsubsection{Conclusion}

Based on the results of the $F$ test analysis, the $F_{\text {count }}$ value is 25.974 with a probability of 0.000 . Therefore the calculation results show that $F_{\text {count }}>F_{\text {table }}$ and $p<0.05$, so that $\mathrm{H}_{0}$ is rejected and $\mathrm{Ha}$ is accepted, which means the model above is fit (fit) or means that the selection of tax, regional retribution and regional wealth management variables is a predictor of Local Original Revenue is appropriate, so that tax revenue, regional retribution and management of regional wealth together have a significant effect on the District / City Original Revenue in the Surakarta Residency in 2012-2016.

\subsubsection{T test}

The $t$ test is used to test the significance of the regression coefficients individually. Regression testing used two-way testing (two tailed test) using $\alpha=5 \%$ which means that the confidence level is $95 \%$. The results of the t test are as follows:

Table 4.9. Accuracy Test Result of Estimator Parameters ( $t$ test)

\begin{tabular}{|l|c|c|c|c|}
\hline \multicolumn{1}{|c|}{ Variable } & $\mathbf{T}_{\text {count }}$ & $\mathbf{t}_{\text {table }}$ & $\boldsymbol{p}$ & Description \\
\hline Tax revenue & 2,936 & 2,042 & 0,006 & $\mathrm{H}_{1}$ accepted \\
Regional Retribution & 1,015 & 2,042 & 0,318 & $\mathrm{H}_{2}$ rejected \\
Wealth Management & 3,811 & 2,042 & 0,001 & $\mathrm{H}_{3}$ accepted \\
\hline
\end{tabular}

Source: Statistics Indonesia, 2018 processed

\subsubsection{Effect of Tax Revenue on Regional Original Income}

Testing steps for the influence of tax revenue on the Regency / City Regional Original Revenue in the Surakarta Residency in 2012-2017 are as follows:

a. Hypothesis Determination

Ho : $b_{1}=0$, it means that tax revenue does not have a significant effect on the Original District / City Revenue in the Surakarta Residency in 20122016.

Ha $: b_{1} \neq 0$, meaning that tax revenue has a significant effect on the District / City Original Revenue in the Surakarta Residency in 2012-2016.

b. Determine the level of significant In this study the level of significant $\alpha$ $=0.05$ was used. With a level of significant $\alpha=0.05$ obtained t table as follows:

$$
\begin{aligned}
\mathrm{t}_{\text {table }} & =\alpha / 2, \mathrm{n}-\mathrm{k} \\
& =0,05 / 2,35-4 \\
& =0,025,31 \\
& =2,042
\end{aligned}
$$

c. Testing criteria

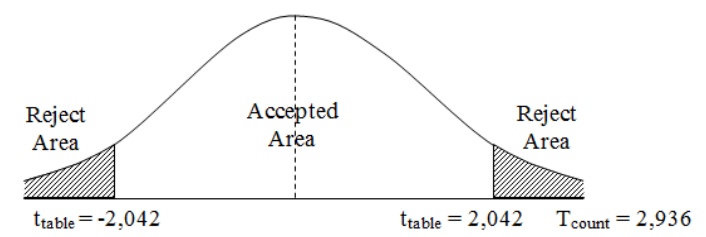

Ho accepted if: $-2,042 \leq \mathrm{t}_{\text {count }} \leq 2,042$ Ho rejected if: $t_{\text {count }}>2,042$ atau $t_{\text {count }}$ $<-2,042$

d. Calculation of the value of $t$ 
ISSN: 2614-1280, http://www.jurnal.stie-aas/ijebar

The results of calculations carried out with the help of SPSS 20.0 for Windows obtained $\mathrm{t}_{\text {count }}$ of 2.936 .

e. Conclusion

The results of calculations for the effect of tax revenue on the District / City Original Revenue in Surakarta Residency in 2012-2016 obtained the value of $\mathrm{t}_{\text {count }}$ of 2.936 and $\mathrm{p}=0.006$ with the regression coefficient value (b1) of 0.479 with positive parameters. Therefore the $t_{\text {count }}$ value is greater than $t$ table $(2.936>2.042)$ and the probability is $0.006<0.05$; so that $\mathrm{H} 0$ is rejected and $\mathrm{H} 1$ is accepted, which means that tax revenue has a significant effect on the Original District / City Revenue in the Surakarta Residency in 2012-2016.

3.2.4.2 Effect of Regional Retribution on Regional Original Income

The testing steps for the influence of regional retribution on Regency / City Regional Original Revenue in the Surakarta Residency in 2012-2017 are as follows:

a. Hypothesis Determination

Ho : $b_{2}=0$, it means that the regional retribution does not significantly influence the Original District / City Revenue in the Surakarta Residency in 2012-2016.

$\mathrm{Ha}: \mathrm{b}_{2} \neq 0$, it means that the regional retribution has a significant effect on the Original District / City Revenue in the Surakarta Residency in 20122016.

b. Determine the level of significant In this study the level of significant $\alpha$ $=0.05$ was used. With a level of significant $\alpha=0.05$ obtained t table as follows:

$$
\begin{aligned}
\mathrm{t}_{\text {table }} & =\alpha / 2, \mathrm{n}-\mathrm{k} \\
& =0,05 / 2,35-4 \\
& =0,025,31 \\
& =2,042
\end{aligned}
$$

c. Testing criteria

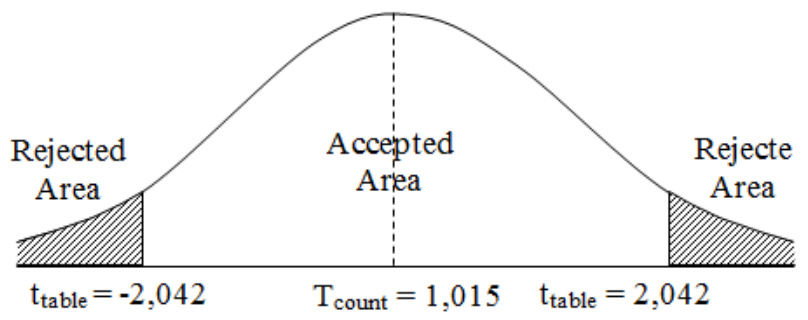

Ho accepted if: $-2,042 \leq \mathrm{t}_{\text {countg }} \leq 2,042$ Ho rejected: $t_{\text {count }}>2,042$ or $t_{\text {count }}<-$ 2,042

d. Calculation of the value of $t$ The results of calculations carried out with the help of SPSS 20.0 for Windows obtained $t_{\text {count }}$ of 1.015 .

e. Conclusion

The results of calculations for the influence of regional retribution on District / City Original Revenue in Surakarta Residency in 2012-2016 obtained $\mathrm{t}_{\text {count }}$ of 1.015 and $\mathrm{p}=0.318$ with regression coefficient value (b2) of 0.788 with positive parameters. Therefore $t_{\text {count }}$ is smaller than $t$ table (1.015 <2.042) and probability is $0.318>0.05$; so that $\mathrm{H} 0$ is accepted and $\mathrm{H} 2$ is rejected, which means that the regional retribution does not significantly influence the Original 
ISSN: 2614-1280, http://www.jurnal.stie-aas/ijebar

District / City Revenue in the Surakarta Residency in 2012-2016.

3.2.4.3 Effect of Wealth Management on Regional Original Income

The testing steps for the influence of the management of regional wealth on the Original District / City Revenue in the Surakarta Residency in 2012-2017 are as follows:

a. Hypothesis Determination

Ho : $b_{2}=0$, meaning that the management of regional wealth does not have a significant effect on the Original Revenue of Regency / City in the Surakarta Residency in 20122016.

Ha : $b_{3} \neq 0$, it means that the management of regional wealth has a significant effect on the Original Revenue of Regency / City in the Surakarta Residency in 20

b. Determine the level of significant

In this study the level of significant $\alpha$ $=0.05$ was used. With a level of significant $\alpha=0.05$ obtained $t$ table as follows:

$$
\begin{aligned}
\mathrm{t}_{\text {table }} & =\alpha / 2, \mathrm{n}-\mathrm{k} \\
& =0,05 / 2,35-4 \\
& =0,025,31 \\
& =2,042
\end{aligned}
$$

c. Testing criteria

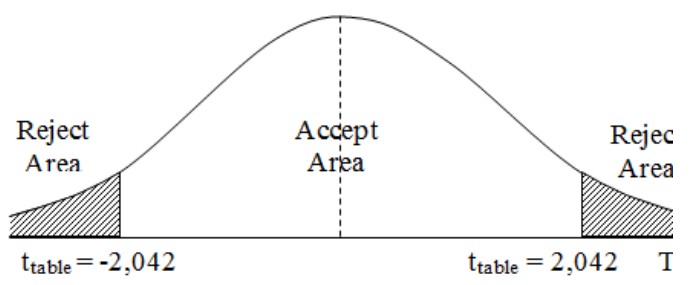

Ho accepted if: $-2,042 \leq \mathrm{t}_{\text {count }} \leq 2,042$ Ho rejected if: $t_{\text {count }}>2,042$ or $t_{\text {count }}<$ $-2,042$

d. Calculation of $t$ value

The results of calculations carried out with the help of SPSS 20.0 for windows obtained $t$ count of 3.811 .

e. Conclusion

The calculation results for the influence of the management of regional wealth on the District / City Original Revenue in the Surakarta Residency in 2012-2016 obtained $t_{\text {count }}$ of 3.811 and $p=0.001$ with the regression coefficient value (b3) of 11.228 with positive parameters. Therefore the value of $\mathrm{t}$ count is greater than t table $(3.811>2.042)$ and the probability is $0.001<0.05$; so that $\mathrm{H} 0$ is rejected and $\mathrm{H} 3$ is accepted, which means that the management of regional wealth has a significant effect on the Original District / City Revenue in the Surakarta Residency in 20122016.

\section{Discussion}

The most central government revenue is tax, the tax contribution to the government budget is very large, so the role of tax is so central. For this reason, the government always strives to increase income from the tax sector, through efforts to eradicate the tax mafia. The government is currently improving its tax system because the old system is considered to have many weaknesses, this is done to secure state income from the tax sector so as not to leak, this effort is carried out so that state revenues from taxes from years continue to increase. 
ISSN: 2614-1280, http://www.jurnal.stie-aas/ijebar

Development independence is needed both at the central level and at the regional level. This is inseparable from the success of the implementation of provincial and city or city government which is an integral part of the central government with its policies. The policy on regional finance is taken by the central government so that the regional government has the ability to finance regional development in accordance with the principles of the autonomous region. Regional financing first, comes from the central government only. With the existence of autonomy, financing not only comes from the center but also comes from its own region, so that the local government tries to increase the Regional Original Revenue itself. To increase Regional Original Revenue, the government tries to improve its regional tax system. Local tax is the largest income obtained by the region.

Based on the results of research on the effect of the influence of local tax revenue, regional retribution and management of regional wealth on the District / City Regional Original Revenue in the ExSurakarta Residency in 2012-2016 the following results were obtained:

The results of calculations for the effect of tax revenue on the District / City Original Revenue in Surakarta Residency in 2012-2016 obtained the value of tcount of 2.936 and $p=0.006$ with the regression coefficient value (b1) of 0.479 with positive parameters. Therefore the tcount value is greater than t table $(2.936>2.042)$ and the probability is $0.006<0.05$; so that $\mathrm{HO}$ is rejected and $\mathrm{H} 1$ is accepted, which means that tax revenue has a significant effect on the Original District / City
Revenue in the Surakarta Residency in 2012-2016.

The most central government revenue is tax, the tax contribution to the government budget is very large, so the role of tax is so central. For this reason, the government always strives to increase income from the tax sector, through efforts to eradicate the tax mafia. The government is currently improving its tax system because the old system is considered to have many weaknesses, this is done to secure state income from the tax sector so as not to leak, and this effort is carried out so that state revenues from taxes from years continue to increase.

The results of calculations for the influence of regional retribution on District / City Original Revenue in Surakarta Residency in 2012-2016 obtained tcount of 1.015 and $\mathrm{p}=0.318$ with regression coefficient value (b2) of 0.788 with positive parameters. Therefore tcount is smaller than $\mathrm{t}$ table $(1.015<2.042)$ and probability is $0.318>0.05$; so that $\mathrm{HO}$ is accepted and $\mathrm{H} 2$ is rejected, which means that the regional retribution does not significantly influence the Original District / City Revenue in the Surakarta Residency in 2012-2016.

According to Law Number 34 of 2000, Regional Retribution is a regional levy as payment for services or granting certain specific permits provided and or provided by the local government for the benefit of individuals or entities (Suandy, 2005).

Development independence is needed both at the central level and at the regional level. This is inseparable from the success of the implementation of provincial and 
city or city government which is an integral part of the central government with its policies. The policy on regional finance is taken by the central government so that the regional government has the ability to finance regional development in accordance with the principles of the autonomous region. Regional financing first, comes from the central government only. With the existence of autonomy, financing not only comes from the center but also comes from its own region, so that the local government tries to increase the region's own original income. To increase local revenue, the government tries to improve its regional tax system. Local tax is the largest income obtained by the region.

Results of the calculations for the effect of the wealth management area of the Revenue District / City in Surakarta in 2012-2016 was obtained tcount of 3.811 and $\mathrm{p}=0.001$ by regression coefficient (b3) amounted to 11.282 with a positive parameter. Therefore the value of $t$ count is greater than table $(3.811>2.042)$ and the probability is $0.001<0.05$; so that $\mathrm{H} 0$ is rejected and $\mathrm{H} 3$ is accepted, which means that the management of regional wealth has a significant effect on the Original District / City Revenue in the Surakarta Residency in 2012-2016.

The results of the separated management areas are regional revenues derived from the management of regional assets that are separated, broken down according to the object of income which includes the share of profits on capital participation in regional-owned companies (BUMD). Indicators Results Wealth Management area is a return on equity in the companies belonging to the region (enterprises), part of the return on its investment in state-owned enterprises (SOEs) and part of the return on equity participation in private-owned enterprises and community groups (Mardiasmo, 2002).

Effect of Acceptance of Taxes, Levies and Wealth Management of the Revenue Daerah.Berdasarkan F test analysis results Fhitung 25.974 values obtained with a probability of 0.000 . Therefore, the calculation results show that $\mathrm{F}$ count $>\mathrm{F}$ table and $\mathrm{p}<0.05$, so $\mathrm{H} 0$ is rejected and $\mathrm{Ha}$ accepted, which means that the model above is correct (fit) or mean that the selection of variables tax revenue, levies and wealth management area as a predictor of Local Original Revenue is appropriate, so that tax revenue, regional retribution and management of regional wealth together have a significant effect on the District / City Original Revenue in the Surakarta Residency in 2012-2016.

Regional Original Income (PAD) according to Law Number 33 of 2004 by Septian Dwi Kurniawan consists of regional revenues from the regional tax sector, regional retribution, the results of regionally owned companies, the results of the processing of separated regional assets, and other legitimate income. The Act also states that the purpose of Regional Original Revenue is to give the regions freedom to explore funding for the implementation of regional autonomy as a manifestation of decentralization.

One effort to see the ability of the region in the context of self-support in terms of regional finance in order to reduce dependence on the central 
government, is to look at the composition of the existing regional revenues. The greater the composition of Regional Original Revenue, the greater the ability of local governments to assume greater responsibility. But the smaller the composition of Regional Original Revenue towards regional revenues, the greater dependence on the center. While the impact felt by the community with an increase in revenue from the region's original revenue is the smooth development. Development includes various sectors including road construction, construction of public facilities and other facilities (Kurniawan, 2010). The Most Dominant Factors Affect District / City Original Revenue in ExSurakarta Residency 2012-2016. The calculation results show that tax revenue has a value of beta coefficient of 0.442 which is greater than the variable regional levies and regional wealth management. This shows that tax revenue is more dominant in influencing the Original District / City Revenue in the Surakarta Residency.

Regional Original Income is an income that shows an area's ability to collect sources of funds to finance routine and development activities. So the understanding of Regional Original Revenue can be said to be routine income from the efforts of local governments in utilizing the potential of their regional financial resources to finance their duties and responsibilities (Kurniawan, 2010). Regional Tax is a tax that has the authority to collect it from the regional government whose implementation is carried out by the Regional Revenue Service. Regional
Taxes are regulated in law and the results will go to the Regional Budget (APBD). Regional Taxes which are regulated in Law Number 18 of 1997 as amended by Act Number 34 of 2000 concerning Regional Taxes and Regional Retributions consisting of 4 types of Level I Regional Taxes and 7 types of Level II Regional Taxes (Suandy, 2005).

The Surakarta Residency is one of the major cities in Central Java Province. In order to improve the welfare of the community, the Regency / City Government in the Surakarta Residency is trying to increase local revenue, one of which is through regional taxes and levies, as well as the results of separated regional wealth management. In the Surakarta Residency the local tax collection system is different from the central government tax. The difference lies in the withdrawal system, local taxes in the Regency / City of Surakarta Residency are directly withdrawn by government employees and there are certain taxes, where taxpayers can pay directly at the office that directly handles regional income, in this case the Surakarta Residency is assigned to the DPPKA . Local retribution collection system uses tickets. Tickets are proof of payment from providing services to the public. This difference minimizes the existence of leaks from local revenue from the local tax and regional retribution sectors. And no less important is the existence of a share of profits on equity participation in regional-owned companies (BUMD). With this in mind, it is expected that it will increase local revenue from local taxes, regional retribution and the results of regional wealth management. 
There is a close link between regional revenues, economic development and community welfare. Where the higher the revenue received by the region, the higher the opportunity to develop regional economy and the welfare of the community.

\section{Conclusion}

(1). To further increase the contribution of levies to revenue from $\mathrm{PAD}$, the local government must really explore the potential of the region that can contribute to increasing retribution. For example the assertiveness in parking fees at the edge of the road that has decreased a lot, which can be done by setting parking fees for car owners who only park their cars on the side of the road where they do not have their own parking space or yard in their homes, are subject to parking fees at night rates. (2). In order for the level of achievement of regional retribution targets to be more effective, local governments are required to really collect all available potential so that the realization that will be received is in accordance with the planned targets. Because, sometimes there is a potential or asset that must be obliged to pay retribution but not collected or missed so that the realization received is not in accordance with the expected target before. (3). Local governments are required to pay close attention to each collection of potential regional levies. For example, do not ignore the obligatory retribution that only gives a small input, because this will affect the acceptance of PAD. So the greater the receipt of regional retribution, the greater the PAD that will be received. So that the increase in regional retribution greatly influences the PAD revenue or it can be said that the regional retribution is elastic towards $\mathrm{PAD}$

\section{Reference}

Arief, Sritua. 2013. Metodologi Penelitian Ekonomi. Jakarta:UI-Press.

Anggraeni, Rima. 2009. Anaisis Penerimaan Pajak Daerah dalam PeningkatanPendapatan Asli Daerah dan Kesejahteraan Hidup Masyarakat Kota Malang. Skripsi Universitas Negeri Malang.

E. Case, Karl dan Ray C. Fair. 2010. Prinsip-Prinsip Ekonomi. Jakarta: Erlangga.

Erly Suandy. 2013. Hukum Pajak. Edisi Ketiga. Jakarta : Salemba Empat.

Gujarati, Damodar. 2012. Ekonometrika Dasar. Jakarta: Erlangga.

Jamli, Ahmad. 2012. Teori Ekonomi Makro. Yogyakarta: BPFE.

Mankiw, N. Gregory. 2014. Pengantar Ekonomi Makro. Jakarta: Salemba Empat.

Mardiasmo. 2012. Perpajakan. Yogyakarta: Andi Yogyakarta.

Martani Setyawati. 2010. Analisis Pengaruh Penerimaan Retribusi Daerah terhadap Pendapatan Asli Daerah Kabupaten Sragen. Tesis. Universitas Sebelas Maret Sukoharjo.

Md. Krisna Arta Anggar Kusuma dan Ni Gst. Putu Wirawati. 2013. Analisis Pengaruh Penerimaan Pajak Daerah dan Retribusi Daerah terhadap Peningkatan PAD SeKabupaten/Kota di Provinsi Bali. 
International Journal of Economics, Business and Accounting Research (IJEBAR)

Peer Reviewed - International Journal

Vol-2, Issue-3, 2018 (IJEBAR)

ISSN: 2614-1280, http://www.jurnal.stie-aas/ijebar

E-Jurnal Akuntansi Universitas Udayana 5.3 (2013):574-585.

Sukandarrumidi. 2012. Metodologi Penelitian. Yogyakarta: Gadjah Mada University Press.

STIE Wijaya Mulya Sukoharjo, 2012, Pedoman Penulisan Skripsi, team penyusun, Sukoharjo

Tjahjono, Achmad dan Muhammad F. Husain. 2011. Perpajakan.
Yogyakarta: Akademi Manajemen Perusahaan YKPN.

Widarjono, Agus. 2014. Ekonometrika. Yogyakarta: Ekonosia.

Widhi Ardiasyah, Indra. 2015. Analisis Kontribusi Pajak Hotel Dan RestoranTerhadap Pendapatan Asli Daerah Kabupaten Purworejo Tahun 1989-2003. Sripsi, Fakultas Ekonomi Universitas Islam Indonesia, Yogyakarta 